\title{
PENAMBAHAN AIR KELAPA (COCOS NUCIFERA L) DAN AIR LINDI (LEACHATE) SEBAGAI AKTIVATOR PEMBUATAN KOMPOS
}

\author{
Addition Of Cococnut Water (Cococs Nucifera L) And Leachate As An Activator \\ For Making Compost \\ Sulasmi, Nur Syamsih \\ Jurusan Kesehatan Lingkungan Poltekkes Kemenkes Makassar \\ Laksmi.kesling@gmail.com
}

\begin{abstract}
Garbage is unwanted residual material that comes from human activities. The impact of this waste is environmental pollution. So it is necessary to manage waste by making compost where compost is organic material that has been decomposed and used as planting medium, fertilizer, and soil fertilizer. This research is to determine the addition of coconut water (cocos nucifera I) and leachate as activator of composting. This research is quasi-experimental research and the data are analyzed descriptively. The results showed that of the 4 variables studied, the addition of coconut water activator (cocos nucifera I) with concentration of 150 occurred for $25 \mathrm{ml}$ and $250 \mathrm{ml}$ occurred for 20 days and leachate with a concentration of 150 occurred for $23 \mathrm{ml}$ and 250 days. $\mathrm{ml}$ occurred for 16 days and without the addition of activator occurred for 29 days. This shows that the addition of activator can accelerate composting compared to without using an activator. It was concluded that the addition of coconut water activator (cocos nucifera l) with a concentration of $150 \mathrm{ml}$ and $250 \mathrm{ml}$ and leachate (leachate) with concentration of $150 \mathrm{ml}$ and $250 \mathrm{ml}$ could accelerate composting than without the addition of activator with odor characteristics such as soil, blackish brown color. and crumb texture. It is hoped that the results of this research can be alternative for controlling organic waste as the main ingredient in making compost.
\end{abstract}

Keywords: Coconut Water (Cocos Nucifera L), Leachate (Leachate), Decomposition Time, Physical Quality of Compost

\section{ABSTRAK}

Sampah merupakan material sisa yang tidak diinginkan berasal dari aktivitas manusia. Dampak ditimbulkan sampah yaitu pencemaran lingkungan. Sehingga perlu pengelolaan sampah dengan cara membuat kompos dimana kompos merupakan material organik yang sudah didekomposisi dan digunakan sebagai media tanam, pupuk, dan penyubur tanah. Penelitian ini untuk mengetahui penambahan air kelapa (cocos nucifera l) dan air lindi (leachate) sebagai aktivator pembuatan kompos. Merupakan penelitian eksperimen semu, data dianalisa secara deskriptif. Hasil menunjukka dari 4 variabel yang diteliti pada penambahan aktivator air kelapa (cocos nucifera l) dengan konsentrasi $150 \mathrm{ml}$ selama 25 hari dan $250 \mathrm{ml}$ terjadi selama 20 hari dan air lindi (leachate) dengan konsentrasi 150 terjadi selama 23 hari dan $250 \mathrm{ml}$ terjadi selama 16 hari dan tanpa penambahan aktivator terjadi selama 29 hari. Hal ini menunjukkan bahwa penambahan aktivator dapat mempercepat pengomposan dibandingkan dengan tanpa menggunakan aktivator. Disimpulkan bahwa penambahan aktivator air kelapa (cocos nucifera l) dengan konsentrasi $150 \mathrm{ml}, 250 \mathrm{ml}$ dan air lindi (leachate) dengan konsentrasi $150 \mathrm{ml}$ dan $250 \mathrm{ml}$ dapat mempercepat pengomposan dari pada tanpa penambahan activator. Diharapkan hasil penelitian ini dapat menjadi salah satu alternatif pengendalian sampah organik sebagai bahan utama dalam pembuatan kompos.

Kata Kunci: Air Kelapa (Cocos Nucifera L), Air Lindi (Leachate), Lama Waktu Dekomposisi, Kualitas Fisik Kompos

\section{PENDAHULUAN}

Menurut WHO (World Health Organization), sampah merupakan suatu materi yang tidak digunakan, tidak terpakai, tidak disenangi, atau sesuatu yang dibuang yang berasal dari kegiatan manusia. Keberadaan sampah inilah yang tidak dapat dihindari dan harus dikelola dengan baik karena pengelolaan sampah yang tidak efektif dapat mengakibatkan terjadinya pencemaran lingkungan. Kondisi tersebut dapat mengakibatkan terjadinya penurunan kualitas lingkungan hidup. Dampak yang ditimbulkan dari sampah dimana penghasil sampah tidak melakukan penanganan dengan baik sehingga mencemari lingkungan sekitarnya.

Kementerian Lingkungan Hidup mencatat rata-rata penduduk Indonesia menghasilkan sekitar $0,5 \mathrm{~kg}$ sampah per hari atau 125 juta sampah dari jumlah penduduk Indonesia. Data Bank Dunia menyebutkan jumlah sampah padat yang diproduksi secara nasional mencapai 151.921 ton per hari. Berarti, Hal ini berarti, setiap penduduk Indonesia membuang sampah padat sebesar $0,85 \mathrm{~kg}$ setiap hari dari total sampah tersebut hanya $80 \%$ yang berhasil dikumpulkan (Rehas \& Pasaribu, 2017).

Di Kota Makassar sendiri sebenarnya telah tersedia banyak tempat membuang sampah begitu juga dengan truk pengangkut sampah dan fasilitas lainnya, tetapi tetap saja masalah sampah di Kota Makassar belum teratasi. Dengan jumlah penduduk kurang lebih mencapai 1,6 juta jiwa, menghasilakn sekitar 4500 meter kubik sampah setiap harinya. Sehingga dapata di prediksikan volume sampah di kota Makassar cukup tinggi.

Sampah padat/limbah padat yang dihasilkan dalam jumlah yang cukup besar, sampah padat ini merupakan limbah sisa sayuran rumah tangga atau yang berasal dari pasar yang hanya ditumpuk ditempat pembuangan dan selanjutnya dibuang ke TPA dan tidak 
Jurnal Sulolipu : Media Komunikasi Sivitas Akademika dan Masyarakat

Vol. 21 No.2 2021

e-issn : 2622-6960, p-issn : 0854-624X

dikelola dengan baik. Dari penumpukan inilah terdapat suatu cairan dimana seringa di katakana air lindi. Lindi mengandung mikroba dan berbagai macam mineral yang dibutuhkan untuk pertumbuhan bakteri dalam proses fermentasi kompos ( Farumi, 2020).

Lindi berasal dari tumpukan sampah yang dapat memicu penyebab terjadinya suatu pencemaran dan tempat per kembangbiakan binatang pengganggu seperti kecoa, lalat, tikus. Selain itu, permasalahan yang terjadi adalah timbulnya bau busuk dan menjadi sarang timbulnya penyakit. Untuk mengatasi permasahan tersebut sehingga dapat mengurangi dampak yang ditimbulkan air lindi dan dapat dimanfaatkan kembali sebagai bahan untuk membuat MOL yang digunakan sebagai aktivator dalam pembuatan kompos.

Banyak masyarakat yang belum mengetahui manfaat dan kandungan air kelapa terhadap tanaman. Limbah dari air kelapa tersebut dihasilkan mengandung mineral yang masih dapat dimanfaatkan. Sehingga Air kelapa dapat dimanfaatkan sebagai aktivator dalam pembuatan kompos untuk meningkatkan produktivitas dan hasil produksi tanaman.

Berdasarkan hasil penelitian Riska Hamsah (2018), kompos yang diperoleh dalam penggunaan aktivator air kelapa dengan konsentrasi $250 \mathrm{ml}$ mampu mendekomposisi sampah organik selama 25 hari, dan konsentrasi $100 \mathrm{ml}$ mampu mendekomposisi sampah organik selama 28 hari. Sedangkan pada proses pengomposan tanpa aktivator mampu mendekomposisi sampah organik selama 28 hari dengan kualitas kompos yang bagus dan sesuai dengan SNI. Menurut Luqman (2013) pemanfaatan limbah sayursayuran untuk pembuatan kompos dengan penambahan air kelapa (cocos nucifera I) dan ampas teh sebagai pengganti pupuk kimia pada tanaman semangka (citrullus vulgaris I) diperoleh hasil bahwa air kelapa $250 \mathrm{ml}$ dan ampas teh $8 \mathrm{~kg}$ menunjukkan pertumbuhan tinggi tanaman yang paling besar yang didapatkan $73,3 \mathrm{~cm}$.

Berdasarkan penelitian evelin tahun 2016, bahwa lindi yang berasal dari tumpukan sampah dapat dimanfaatkan dan membantu mempercepat proses pengomposan. Didapatkan hasil dalam proses pengomposan dengan menggunakan air lindi sebanyak 400 $\mathrm{ml}$ dengan campuran EM4 dapat mendekomposisi sampah menjadi kompos selama 7 hari

Oleh karena itu, Berdasarkan uraian diatas, maka perlu melakukan penelitian untuk mengetahui "Penambahan Air Kelapa (Cocos Nucifera L) dan Air Lindi (Leachate) Sebagai Aktivator Pembuatan Kompos.

\section{METODE}

Penelitian ini dilakukan di workshop Jurusan Kesehatan Lingkungan jl. Wijaya Kusuma 1 No. 02 Poltekkes Kemenkes Makassar. Jenis penelitian eksperimen dengan melakukan pengulangan sebanyak tiga kali terhadap kualitas kompos. Penambahan aktivator air kelapa konsentrasi $150 \mathrm{ml}$, dan $250 \mathrm{ml}$, air lindi konsentrasi $150 \mathrm{ml}$,dan konsentrasi 250 $\mathrm{ml}$. Populasi dalam penelitian ini adalah sampah organik sisa sayuran dan ampas teh yang diambil di pasar Kancil Kelurahan Mamajang Luar Kota Makassar. Bahan pembuatan kompos diantaranya limbah sisa sayuran dan ampas teh dengan aktivator air kelapa (cocos nucifera $L$ ) dan air lindi yang merupakan cairan yang berasal dari tumpukan sampah yang diambil dari TPA Tamangapa Antang.

\section{TEKNIK PENGUMPULAN DATA}

1. Data Primer

Data primer diperoleh darihasil pengamatan dan eksperimen langsung dengan cara memperhatikan secara fisik ciri-ciri kompos yang telah matang yaitu bau seperti tanah, warna cokelat kehitaman, dan tidak menggumpal.

2. Data Sekunder

Data sekunder diperoleh dari hasil penelusuran perpustakaan berupa bukubuku, artikel, jurnal, hasil penelitian sebelumnya dan internet serta media informasi lainnya yang dianggap memilki keterkaitan dengan penelitian ini.

\section{PENGOLAHAN DAN ANALISIS DATA}

1. Pengolahan Data

Data yang diperoleh dari hasil pemeriksaan dalam penelitian ini selanjutnya diolah dengan cara komputerisasi. Data yang telah diolah, kemudian disajikan dalam bentuk tabel.

2. Analisis Data

Data dianalisa secara deskriptif dari hasil pemeriksaan kemudian diambil kesimpulan 
Jurnal Sulolipu : Media Komunikasi Sivitas Akademika dan Masyarakat

Vol. 21 No.2 2021

e-issn : 2622-6960, p-issn : 0854-624X

\section{HASIL}

Hasil penelitian yang dilakukan di Workshop Jurusan Kesehan Lingkungan pada bulan Maret-Mei 2021 dengan judul pengaruh penambahan air kelapa (cocos nucifera I) dan air lindi (leachate) sebagai aktivator pembuatan kompos sampah organik dan ampas teh, diperoleh hasil penelitian selama proses pembuatan kompos yaitu dapat dilihat pada sebagai berikut:

\section{PEMBAHASAN}

1. Penambahan aktivator air kelapa (cocos nucifera I) dengan konsentrasi $150 \mathrm{ml}$ dalam proses pengomposan

Hasil penelitian, dengan penambahan aktivator pada proses pengomposan menggunakan aktivator air kelapa (cocos nucifera l) konsentrasi $150 \mathrm{ml}$ mampu mempercepat proses pengomposan. Sehingga dapat dilihat bahwa kompos yang sudah matang memiliki ciri-ciri bau seperti tanah, warna coklat kehitaman dan tekstur remah.

Hasil pengamatan lama waktu kematangan yang telah dilakukan pada proses pengomposan menggunakan aktivator air kelapa (cocos nucifera I) konsentrasi $150 \mathrm{ml}$ mampu mempercepat proses pengomposan sampah organik dan ampas teh dibanding dengan kompos yang tanpa perlakuan (kontrol) dengan hasil diperoleh kematangan pada hari ke 25 .

Hasil penelitian ini sejalan dengan Riska Hamsah (2018), kompos yang diperoleh dalam penggunaan aktivator air kelapa dengan konsentrasi $100 \mathrm{ml}$ mampu mendekomposisi sampah organik selama 28 hari. Hal ini menunjukkan konsentrasi $150 \mathrm{ml}$ mampu mendekomposisi kompos lebih cepat dibandingkan dengaan konsentrasi $100 \mathrm{ml}$.

Suhu tertinggi terjadi pada hari pertama dengan penambahan aktivator air kelapa konsentrasi $150 \mathrm{ml}$ dengan suhu $36^{\circ} \mathrm{C}$ dan hari ke dua terus mengalami penurunan hingga hari ke-25 diperoleh hasil yag ideal. Peningkatan suhu pada proses dekomposisi terjadi karena berkaitan dengan keberadaan bakteri pengurai yang bermanfaat untuk mempercepat proses dekomposisi dengan menghancurkan bahan organik dan menghilangkan bau busuk. Selanjutnya suhu mengalami kenaikan kemudian kembali turun mendekati suhu ruang dengan diperoleh suhu $33^{\circ} \mathrm{C}$. penurunan suhu disebabkan oleh penurunan metabolisme mikroba karena bahan sudah terdekomposisi.

Selain kondisi temperatur, hasil pengukuran $\mathrm{pH}$ dari hari pertama hingga hari kelima tidak mengalami perubahan yaitu diperoleh $\mathrm{pH}$ dengan nilai 7,5 . Padah hari ke 7 sampai hari ke $15 \mathrm{pH}$ mengalami penurunan hingga diperoleh $\mathrm{pH}$ dengan nilai 7 . Hal tersebut dikarenakan pada saat minggu pertama kompos mengalami proses dekomposisi yang menyebabkan pengomposan sudah memasuki proses dekomposisi mulai terhenti yang mengakibatkan diperoleh hasil $\mathrm{pH}$ yang ideal.

Proses pengomposan menyebabkan perubahan bahan organik dan $\mathrm{pH}$. Sebagai contoh, proses pelepasan asam, secara local atau temporer, akan menyebabkan penurunan $\mathrm{pH}$ (pengasaman), sedangkan produksi ammonia dari senyawa-senyawa yang mengandung nitrogen akan meningkatkan $\mathrm{pH}$ pada fase awal penomposan. $\mathrm{pH}$ kompos yang sudah matang biasanya mendekati netral.

Menurut Lukman (2013) pemanfaatan limbah sayuran-sayuran untuk pembuatan kompos dengan penambahan air kelapa (cocos nucifera I) dan ampas teh sebagai pengganti pupuk kimia pada tanaman semangka (citrullus vulgaris I) diperoleh hasil bahwa air kelapa $250 \mathrm{ml}$ dan ampas teh $8 \mathrm{~kg}$ menunjukkan pertumbuhan tinggi tanaman yang paling besar didapatkan 73,3 $\mathrm{cm}$. Faktor yang mempengaruhi proses pengomposan yaitu $\mathrm{C} / \mathrm{N}$ bahan baku, jenis bahan baku yang digunakan, ukuran bahan baku, suhu, kelembaban dan aktivator.

Menurut Sumekto (2006), pada proses pengomposan yang ideal, tahap pertama yaitu tahap penghangatan (tahap mesofilik), mikroorganisme hadir dalam kompos secara cepat dan temperatur meningkat. Mikroorganisme mesofilik hidup dalam temperatur $10^{\circ} \mathrm{C}-45^{\circ} \mathrm{C}$. dan bertugas memperkecil ukuran pertikel bahan organik sehingga luas permukaan bahan bertambah dan mempercepat proses pengomposan. Tahap kedua yaitu tahap termofilik, mikroorganisme termofilik hadir dalam tumpukan bahan kompos. Mikroorganisme termofilik hidup pada $45^{\circ} \mathrm{C}$ $60^{\circ} \mathrm{C}$ dan makan karbohidrat protein sehingga bahan kompos dapat terdegradasi dengan cepat. Setelah temperatur puncak terlewati, tumpukan mencapai kestabilan dimana bahan lebih mudah terdekomposisikan. Selanjutnya 
tahap ketiga yaitu tahap pendinginan dan pematangan. Pada tahap ini, jumlah mikroorganisme termofilik berkurang hal ini mengakibatkan organisme mesofilik mulai beraktivitas kembali, tetapi kemampuannya tidak sebaik organisme termofilik.

Penambahan aktivator air kelapa dapat berpengaruh terhadap proses pengomposan karena dapat meningkatkan unsur hara makro, meningkatkan produktivitas tanah dan semakin tinggi konsentrasi pada aktivator air kelapa maka semakin cepat pula proses pengomposan.

2. Penambahan aktivator air kelapa (cocos nucifera l) dengan konsentrasi $250 \mathrm{ml}$

Hasil penelitian dengan penambahan aktivator air kelapa (cocos nucifera I) konsentrasi $250 \mathrm{ml}$ mampu mempercepat proses pengomposan.

Hasil pengamatan lama waktu kematangan dengan menggunakan aktivator air kelapa (cocos nucifera l) konsentrasi $250 \mathrm{ml}$ mampu mempercepat proses pengomposan sampah organik dan ampas teh dibanding dengan kompos yang tanpa perlakuan (kontrol) dengan hasil diperoleh kematangan pada hari ke 20.

Suhu tertinggi terjadi pada hari pertama dengan penambahan aktivator air kelapa konsentrasi $250 \mathrm{ml}$ dengan suhu $37^{\circ} \mathrm{C}$ dan hari ke dua terus mengalami penurunan hingga hari ke-20 diperoleh hasil yag ideal. Peningkatan suhu pada proses dekomposisi terjadi karena berkaitan dengan keberadaan bakteri pengurai yang bermanfaat untuk mempercepat proses dekomposisi dengan menghancurkan bahan organik dan menghilangkan bau busuk. Selanjutnya suhu mengalami kenaikan kemudian kembali turun mendekati suhu ruang dengan diperoleh suhu $30^{\circ} \mathrm{C}$. penurunan suhu ini disebabkan oleh penurunan metabolism mikroba karena semua bahan sudah terdekomposisi.

Rata-rata kadar air menjadi netral (memenuhi standar) pada hari ke-20 yaitu $60 \%$. Kadar air dapat berpengaruh terhadap aktivitas mikroorganisme dalam proses dekomposisi bahan organik.

Penambahan aktivator air kelapa dalam pembuatan kompos sampah organik dan ampas teh berfungsi sebagai starter untuk menstimulir perkembangan mikroba perombak untuk mempercepat proses pengomposan. Penambahan aktivator air kelapa sebagai katalisator untuk mempercepat pengomposan, juga membuat hasil pengomposan menjadi sempurna.

Mikroorganisme yang terlibat proses pengomposan membutuhkan oksigen dan air untuk merombak bahan organik dan mengasimilasikan sejumlah karbon nitrogen, fosfor, dan unsur lainnya. Beberapa mikroorganisme yang terkandung dalam air kelapa (cocos nucifera I) yang berguna bagi tanaman yaitu, aspergillus niger dan pseudomonas putida.

Banyak masyarakat yang belum mengetahui manfaat dan kandungan air kelapa terhadap tanaman. Limbah dari air kelapa mengandung mineral yang masih dapat dimanfaatkan sebagai aktivator dalam pembuatan kompos untuk meningkatkan produktivitas dan produksi tanaman.

3. Penambahan air lindi (leachate) dengan konsentrasi $150 \mathrm{ml}$ dalam proses pengomposan

Hasil dengan penambahan aktivator pada proses pengomposan menggunakan air lindi (leachate) konsentrasi $150 \mathrm{ml}$ mampu mempercepat proses pengomposan. Sehingga dapat dilihat bahwa kompos yang sudah matang memiliki ciri-ciri bau seperti tanah, warna coklat kehitaman dan tekstur remah.

Hasil penelitian pengamatan lama waktu kematangan yang telah dilakukan dengan menggunakan air lindi (leachate) dengan konsentrasi $150 \mathrm{ml}$ mampu mempercepat proses pengomposan sampah organik dan ampas teh dibanding dengan kompos yang tanpa perlakuan (kontrol) dengan hasil diperoleh kematangan pada hari ke 23.

Suhu tertinggi terjadi pada hari pertama dengan penambahan air lindi konsentrasi $150 \mathrm{ml}$ dengan suhu $35^{\circ} \mathrm{C}$ dan hari ke dua terus mengalami penurunan hingga hari ke23 diperoleh hasil yag ideal. Peningkatan suhu pada proses dekomposisi terjadi karena berkaitan dengan keberadaan bakteri pengurai yang bermanfaat untuk 
mempercepat proses dekomposisi dengan menghancurkan bahan organik dan menghilangkan bau busuk. Selanjutnya suhu mengalami kenaikan kemudian kembali turun mendekati suhu ruang dengan diperoleh suhu $30^{\circ} \mathrm{C}$. penurunan suhu ini disebabkan oleh penurunan metabolism mikroba karena semua bahan sudah terdekomposisi.

Hasil sejalan dengan penelitian Sindi (2017) yang menyatakan rata-rata kelembaban pada kompos meningkat sampai $86 \%$. Hal ini dikarena secara perlahan kompos sudah menunjukkan kematangan, tekstur kompos sudah remah dan tidak menggumpal dan kelembaban yang stabil dalam kompos yang sudah matang berkisaran antara $40 \%-60 \%$.

Lindi berasal dari tumpukan sampah dapat penyebabkan terjadinya pencemaran dan tempat perkembangbiakan binatang pengganggu seperti kecoa, lalat, tikus. Selain itu, permasalahan yang terjadi adalah timbulnya bau busuk dan menjadi sarang timbulnya penyakit. Untuk mengatasi permasahan tersebut sehingga dapat mengurangi dampak yang ditimbulkan air lindi dan dapat dimanfaatkan kembali sebagai bahan untuk membuat MOL yang digunakan sebagai aktivator dalam pembuatan kompos.

Meningkatnya jumlah sampah menghasilkan peningkatan volume lindi yang dapat menyebabkan tercemarnya air tanah, hilangnya nilai estetik. Pada kasus pencemaran air tanah, kontaminasi akan berjalan terus menerus dalam periode yang lama sehingga diperlukan suatu cara untuk mengatasi permasalahan tersebut sehingga dapat mengurangi dampak yang ditimbulkan dari air lindi tersebut. Berawal dari permasalahan diatas, timbul suatu pemikiran mengenai sampah pasar yaitu berupa sampah sayur-sayuran dan sampah buahbuahan sebagai salah satu bahan baku pupuk organik dengan memanfaatkan lindi untuk mempercepat proses pengomposan. Air lindi yang digunakan sebagai aktivator pembuatan kompos merupakan cairan yang di hasilkan dari tumpukan sampah yang diambil dari TPA Tamangapa Antang.

4. Penambahan air lindi (leachate) dengan konsentrasi $250 \mathrm{ml}$ dalam proses pengomposan

Hasil dengan penambahan aktivator air lindi (leachate) konsentrasi $250 \mathrm{ml}$ mampu mempercepat proses pengomposan. Hasil pengamatan lama waktu kematangan yang telah dilakukan menggunakan air lindi (leachate) dengan konsentrasi $250 \mathrm{ml}$ mampu mempercepat proses pengomposan sampah organik dan ampas teh dibanding dengan kompos yang tanpa perlakuan (kontrol) dengan hasil diperoleh kematangan pada hari ke 16 .

Hasil penelitian ini sejalan dengan penelitian Evelin (2016), bahwa lindi yang berasal dari tumpukan sampah dapat dimanfaatkan pada proses pengomposan. Hasil proses pengomposan dengan air lindi $400 \mathrm{ml}$ dengan campuran EM4 dapat mendekomposisi sampah menjadi kompos selama 7 hari. Semakin banyak lindi yang ditambahkan maka akan berpengaruh terhadap proses pengomposan.

Lindi merupakan air yang terbentuk dalam timbulan sampah dan melarutkan banyak sekali senyawa yang ada sehingga memiliki kandungan pencemar khususnya zat organik. Namun air lindi mempunyai potensi untuk dimanfaatkan sebagai pupuk organik karena mengandung berbagai macam bahan organik seperti nitrat, mineral dan mikroorganisme. Kandungan zat organik ini akan meningkatkan aktivitas mikroorganisme dalam mendegradasi sampah organik (Dewi dkk, 2016). Dalam kandungan lindi ididentifikasi beberapa genus bakteri aerob seperti streptococcus, Escherichia, pseudomonas dan proteus (Daryat, 2017).

Suhu tertinggi terjadi pada hari pertama dengan penambahan air lindi konsentrasi $150 \mathrm{ml}$ dengan suhu $37^{\circ} \mathrm{C}$ dan hari kedua terus mengalami penurunan hingga hari ke16 diperoleh hasil yang ideal. Peningkatan suhu pada proses dekomposisi terjadi karena berkaitan dengan keberadaan bakteri pengurai yang bermanfaat untuk mempercepat proses dekomposisi dengan menghancurkan bahan organik dan menghilangkan bau busuk. Selanjutnya suhu mengalami kenaikan kemudian kembali turun mendekati suhu ruang dengan diperoleh suhu $30^{\circ} \mathrm{C}$. penurunan suhu ini disebabkan oleh penurunan metabolism mikroba karena semua bahan sudah terdekomposisi.

Kadar air berpengaruh terhadap aktivitas mikroorganisme dalam mendekomposisi bahan organik. Kandungan air dibawah $30 \%$ akan berjalan lambat dan dapat mengakibatkan berkurangnya populasi mikroorganisme pengurai karena 
terbatasnya habitat yang ada. Apabila kelembaban lebih besar dari $60 \%$ hara akan terkunci dan volume udara berkurang akibatnya aktivitas mikroba akan menurun (Sindi, dkk 2017).

Ukuran partikel kompos berhubungan dengan tingkat kematangan kompos dan volume bahan. Semakin matang kompos maka serat kompos semakin sedikit dan dan ukuran partikel juga semakin kecil. Menurut Syukur dan Nur (2006) bahan organic diurai menjadi unsur-unsur yang diserap oleh mikroorganisme, maka ukuran bahan organik berubah menjadi partikel kecil yang menyebabkan volume tumpukan menyusut selama proses pencernaan tersebut. Berat kompos berkurang setengahnya, dikarenakan proses perombakan menghasilkan panas yang menguapkan kandungan air dan $\mathrm{CO}_{2}$ dalam perombakan bahan organik.

5. Kompos tanpa penambahan aktivator dalam proses pengomposan

Pengomposan tanpa menggunakan aktivator mampu mendekomposisi sampah organik dan campuran limbah ampas teh selama 29 hari. Nilai dari pengukuran $\mathrm{pH}$ kompos sampah organik dan campuran limbah ampas teh yaitu 7. Pada awal pengomposan dengan penambahan air lindi (leachate) mencapai 7,5. Pada hari ke $29 \mathrm{pH}$ pada kompos sampai 7 .

Nilai pengukuran suhu pada kompos tanpa menggunakan aktivator selama 29 hari yaitu $31^{\circ} \mathrm{C}$. Dimana pada pengukuran awal pengomposan pada hari ke pertama yaitu $36^{\circ} \mathrm{C}$. Hal ini dikarenakan bahwa bahan yang digunakan dalam proses pengomposan belum terurai dengan baik dan masih adanya aktivitas mikroorganisme pada kompos yang bekerja lebih aktif sehingga suhu meningkat. Pada hari ke 229 suhu sudah mulai menurun sampai $30^{\circ} \mathrm{C}$. Setelah suhu stabil proses pematangan kompos terjadi, kondisi tersebut menunjukkan bahwa sudah ada salah satu ciri dari kematangan kompos yaitu ada beberapa faktor yang dapat mempengaruhi turunnya suhu pada kompos, diantaranya karena kondisi lingkungan sekitar dan adanya perlakuan kompos yang sering dibuka atau dianginanginka

Lama waktu pengomposan dengan penambahan aktivator relatif cepat dibandingkan tanpa menggunakan aktivator yaitu selama 16 hari, sedangkan tanpa menggunakan aktivator selama 29 hari. Kualitas yang terdapat pada penambahan aktivator telah memenuhi persyaratan seperti $\mathrm{pH}$, kelembaban, suhu, bentuk fisik, bau dan warna lebih cepat dibandingkan dengan kompos yang tanpa penambahan aktivator.

Proses pengomposan sangat bermanfaat terhadap lingkungan sebab dapat menyuburkan tanah dan tanaman, memperbaiki struktur dan karakteristik tanah, meningkatkan kapasitas serap air tanah, meningkatkan aktivitas mikroba tanah, membantu melestarikan sumber daya alam dan mengurangi pencemaran lingkungan.

\section{KESIMPULAN}

Kompos pada penambahan aktivator air kelapa (cocos nucifera I) konsentrasi 150 $\mathrm{ml}$ berlangsung selama 25 hari, air kelapa (cocos nucifera l), konsentrasi $250 \mathrm{ml}$ berlangsung selama 20 hari, penambahan air lindi (leachate) konsentrasi $150 \mathrm{ml}$ berlangsung selama 23 hari, air lindi (leachate) konsentrasi $250 \mathrm{ml}$ berlangsung selama 16 hari

\section{SARAN}

Diharapkan hasil penelitian ini dapat menjadi salah satu alternatif pengendalian sampah organik sebagai bahan utama dalam pembuatan kompos.

\section{DAFTAR PUSTAKA}

Daryat Fikri, Zul Delita, Fibriarti, Bernadeta L, 2017. "Analisis Kualitas Air Lindi Asal Tempat Pembuangan Akhir Sampah Kota Pekanbaru Berdasarkan Parameterologi". Jurnal Riau Biologia, 2(1). https://jrb.ejournal.unri.ac.id. (diakses 25 juni 2021).

Evelin Novitasari, Edelbertha, Chandra, 2016. "Pemanfaatan Lindi sebagai Bahan EM4 dalam Proses Pengomposan". TEMU ILMIAH IPLBI, 2016. https://temuilmiah.iplbi.or.id/wpcontent/uploads/2016/12/IPLBI-H-115-120-Pemanfaataan-Lindi-Sebagai-Bahan-EM4-

Dalam-Proses-Pengomposan.pdf (diakses 05 Januari 2021)

Farumi, S. S., Lingkungan, D. K., \& Masyarakat, F. K. (2020). Pengaruh aktivator dalam kompos takakura terhadap tanaman cabai. 5(1), 55-63. http://journal2.um.ac.id. (Diakses 05 Januari 
Jurnal Sulolipu : Media Komunikasi Sivitas Akademika dan Masyarakat

Vol. 21 No.2 2021

e-issn : 2622-6960, p-issn : 0854-624X

2021).

Luqman N.S. (2013). Pemanfaatan Limbah Sayur-Sayuran untuk Pembuatan Kompos dengan Penambahan Air Kelapa (Cocos nucifera) dan Ampas Teh Sebagai Pengganti Pupuk Kimia Pada Pertumbuhan Tanaman Semangka(Citrullus vulgaris L ). (Diakses 12 Juni 2021)

Rehas, A. M., \& Pasaribu, P. (2017). "Tinjauan Terhadap Pengelolaan Sampah Di Kota Samarinda." Yuriska : Jurnal IImiah Hukum, 8(2), 59. https://doi.org/10.24903/yrs.v8i2.155. (Diakses 05 Januari 2021).

Riska Hamsah, juherah juherah. 2018. pemanfaatan air kelapa (cocos nucifera I) sebagai aktivator pembuatan kompos sisa sayuran dan limbah ampas teh. http://jurnal.poltekkesmks.ac.id (diakses 12 Juni 2021).

Sindi M. H, Ganjar Samudro, Sry Sumiati, 2017. Pengaruh Kadar Air Terhadap Hasil Pengomposan Sampah Organik Dengan Metode Composter Tub. Jurnal Teknik Mesin, vol 06. http://media.neliti.com (Diakses 12 Juni 2021).

Sumekto R. 2006. Pupuk Organik. Klaten Jawa Tengah: PT. Intan Sejati, 2006. 
Jurnal Sulolipu : Media Komunikasi Sivitas Akademika dan Masyarakat

Vol. 21 No.2 2021

e-issn : 2622-6960, p-issn : 0854-624X

LAMPIRAN

Tabel 1

Hasil penambahan aktivator pada kualitas fisik kompos

\begin{tabular}{|c|c|c|c|c|}
\hline No. & $\begin{array}{l}\text { Jenis bahan } \\
\text { (Kompos) }\end{array}$ & Bau & Warna & Bentuk Fisik \\
\hline 1. & $\begin{array}{l}\text { Penambahan aktivator air } \\
\text { kelapa dengan konsentrasi } \\
150 \mathrm{ml} \text {. }\end{array}$ & $\begin{array}{l}\text { Seperti } \\
\text { Tanah }\end{array}$ & $\begin{array}{l}\text { Coklat } \\
\text { kehitaman }\end{array}$ & $\begin{array}{l}\text { Tekstur } \\
\text { remah }\end{array}$ \\
\hline 2. & $\begin{array}{l}\text { Penambahan aktivator air } \\
\text { kelapa dengan konsentrasi } \\
250 \mathrm{ml} \text {. }\end{array}$ & $\begin{array}{l}\text { Seperti } \\
\text { Tanah }\end{array}$ & $\begin{array}{l}\text { Coklat } \\
\text { kehitaman }\end{array}$ & $\begin{array}{l}\text { Tekstur } \\
\text { remah }\end{array}$ \\
\hline 3. & $\begin{array}{l}\text { Penambahan air lindi dengan } \\
\text { konsentrsi } 150 \mathrm{ml} \text {. }\end{array}$ & $\begin{array}{l}\text { Seperti } \\
\text { Tanah }\end{array}$ & $\begin{array}{l}\text { Coklat } \\
\text { kehitaman }\end{array}$ & $\begin{array}{l}\text { Tekstur } \\
\text { remah }\end{array}$ \\
\hline 4. & $\begin{array}{l}\text { Penambahan air lindi dengan } \\
\text { konsentrasi } 250 \mathrm{ml} \text {. }\end{array}$ & $\begin{array}{l}\text { Seperti } \\
\text { Tanah }\end{array}$ & $\begin{array}{c}\text { Coklat } \\
\text { kehitaman }\end{array}$ & $\begin{array}{l}\text { Tekstur } \\
\text { remah }\end{array}$ \\
\hline 5. & Tanpa penambahan aktivator. & $\begin{array}{l}\text { Seperti } \\
\text { Tanah }\end{array}$ & $\begin{array}{l}\text { Coklat } \\
\text { kehitaman }\end{array}$ & $\begin{array}{l}\text { Tekstur } \\
\text { remah }\end{array}$ \\
\hline
\end{tabular}

Sumber: Data Primer 2021

Tabel 2

Hasil penambahan aktivator pada lama kematangan kompos

\begin{tabular}{|c|c|c|c|c|c|}
\hline No. & Kompos & & ang & & Rata-rata \\
\hline & & I & II & III & \\
\hline 1. & $\begin{array}{l}\text { Penambahan aktivator air } \\
\text { kelapa dengan } \\
\text { konsentrasi } 150 \mathrm{ml} \text {. }\end{array}$ & 25 & 25 & 24 & 25 \\
\hline 2. & $\begin{array}{l}\text { Penambahan aktivator air } \\
\text { kelapa dengan } \\
\text { konsentrasi } 250 \mathrm{ml} \text {. }\end{array}$ & 20 & 19 & 20 & 20 \\
\hline 3. & 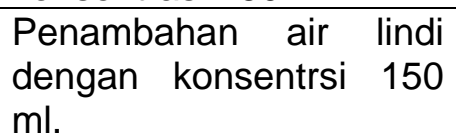 & 23 & 22 & 23 & 23 \\
\hline 4. & $\begin{array}{l}\text { Penambahan air lindi } \\
\text { dengan konsentrasi } 250 \\
\text { ml. }\end{array}$ & 16 & 16 & 15 & 16 \\
\hline 5. & $\begin{array}{ll}\text { Tanpa } & \text { penambahan } \\
\text { aktivator. } & \end{array}$ & 29 & 28 & 29 & 29 \\
\hline
\end{tabular}

Sumber: Data Primer Tahun 2021 
Jurnal Sulolipu : Media Komunikasi Sivitas Akademika dan Masyarakat Vol. 21 No.2 2021

e-issn : 2622-6960, p-issn : 0854-624X

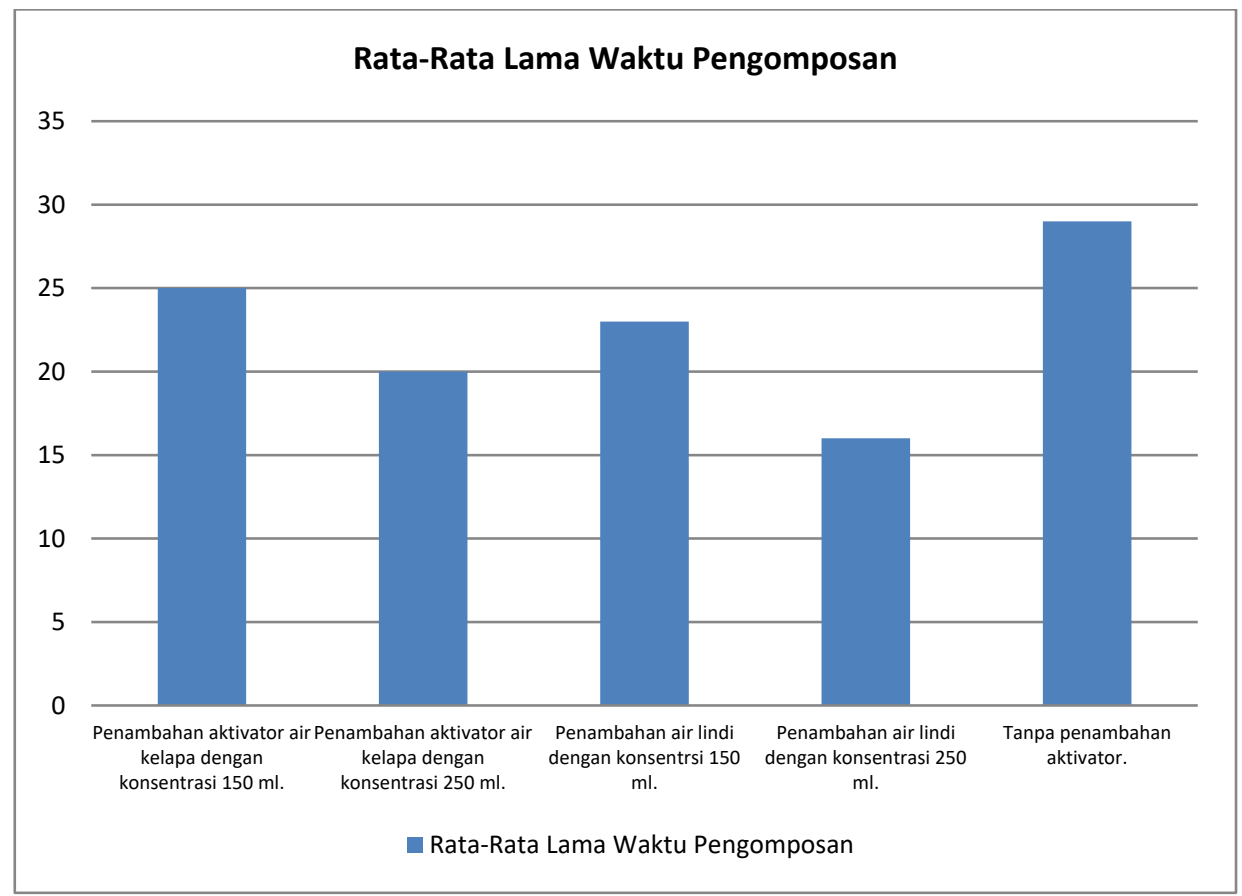

Gambar 1 : Rata-rata Lama Waktu Pengomposan

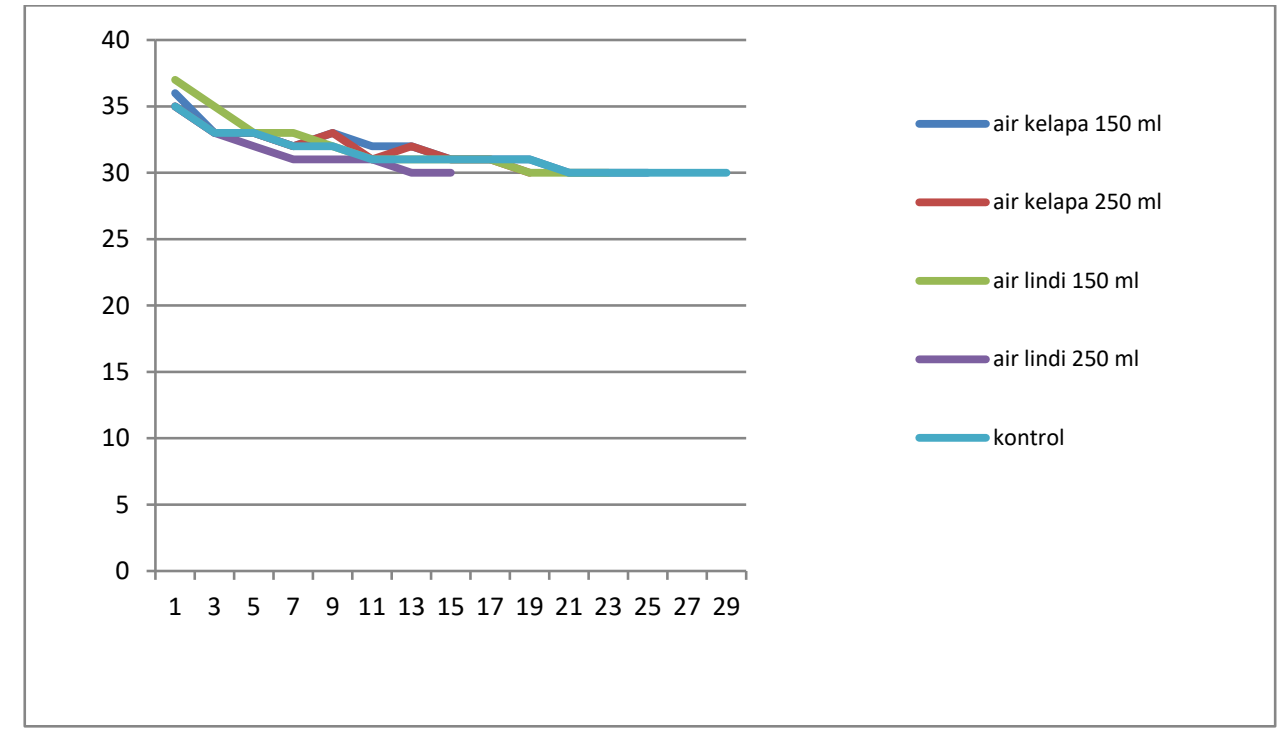

Gambar 2: Hasil Pengukuran Suhu dengan Penambahan Aktivator pada Pembuatan Kompos 
Jurnal Sulolipu : Media Komunikasi Sivitas Akademika dan Masyarakat Vol. 21 No.2 2021

e-issn : 2622-6960, p-issn : 0854-624X

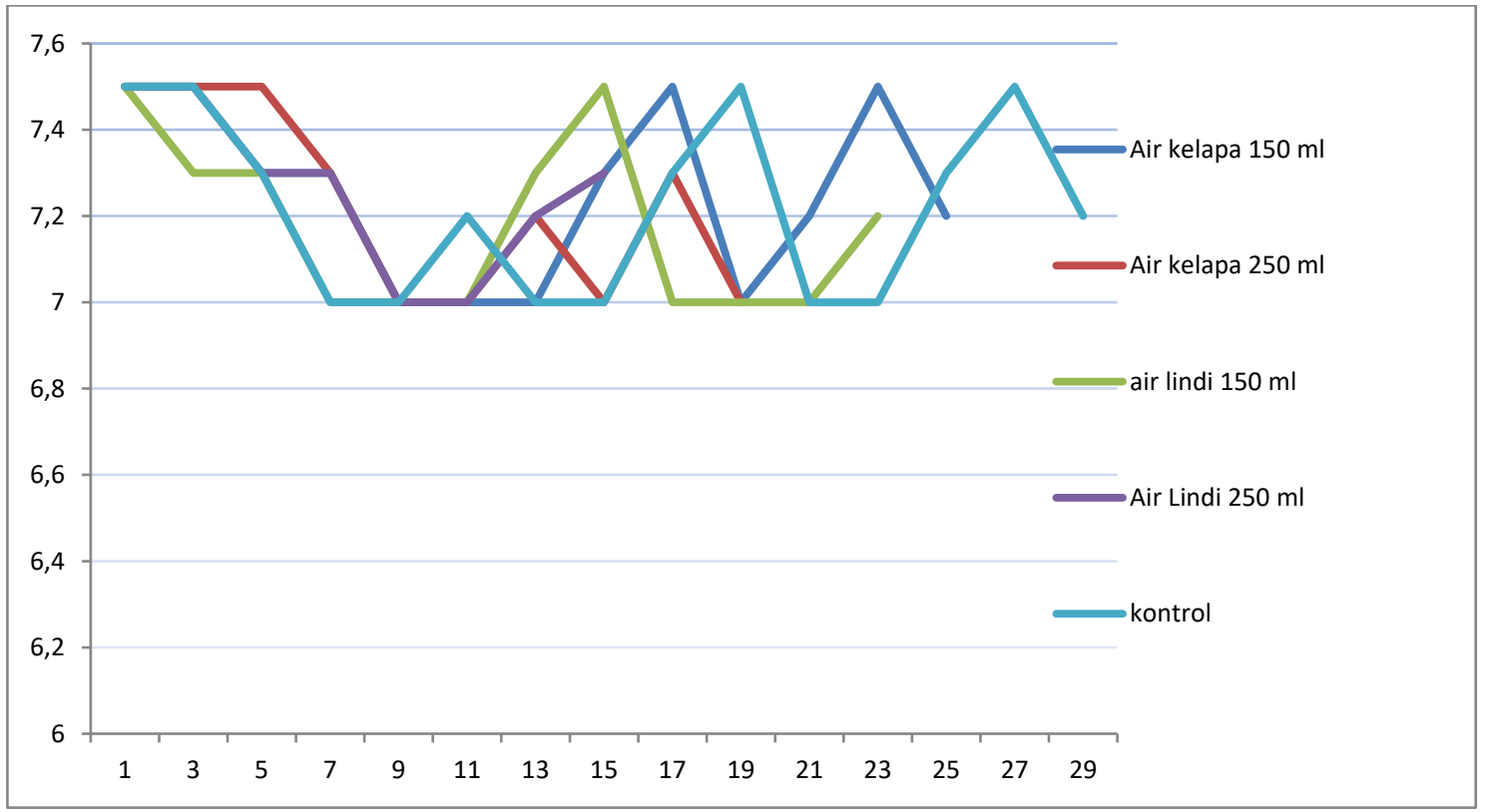

Gambar 3: Hasil Pengukuran pH dengan Penambahan Aktivator pada Pembuatan Kompos

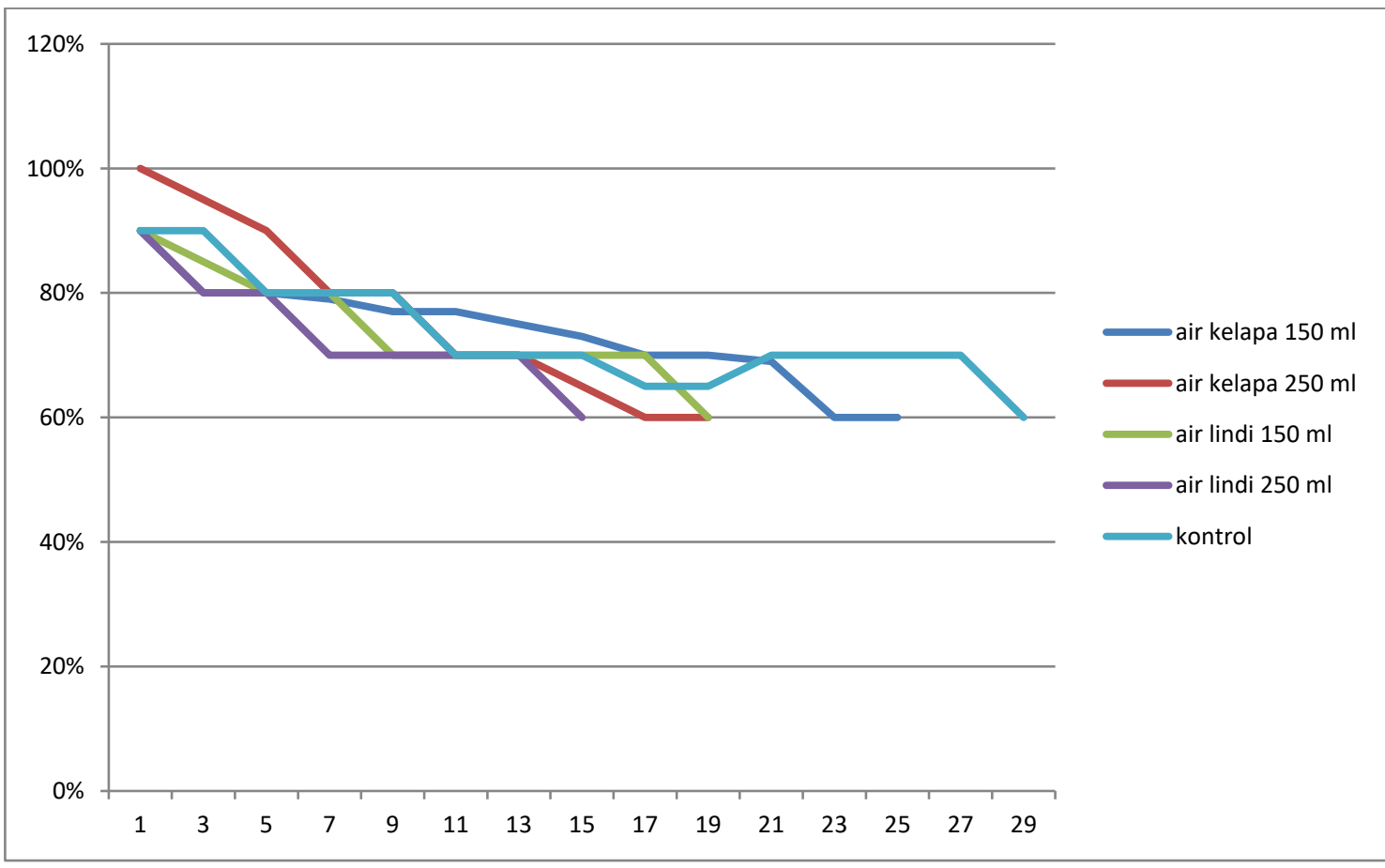

Gambar 4: Hasil Pengukuran Kelembaban demgan Penambahan Aktivator pada Pembuatan Kompos 